\title{
COMPLIMENTARY
}

NEW SERIES VOL. IX

NO. 3

\section{ARNOLD ARBORETULM} HARVARD UNIVERSAYY
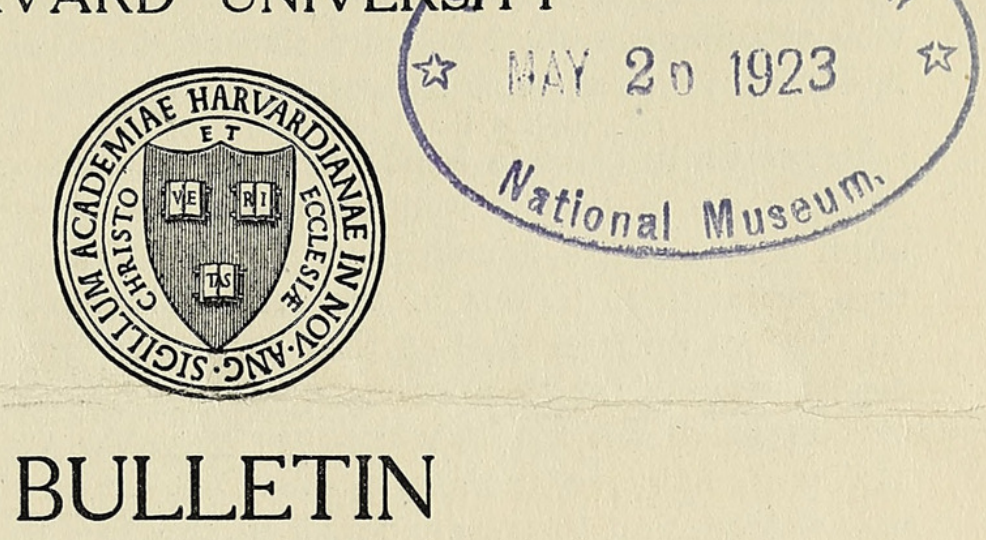

OF

\section{POPULAR INFORMATION}

JAMAICA PLAIN, MASS.

MAY 10,1923

Pear-trees. The Arboretum contains one of the largest collections in the world of the wild types of Pear-trees, especially those from northern and western China. As ornamental trees none of the species from southeastern Europe compare in size or in beauty of foliage and flowers with several of the Chinese species, among which are some of the handsomest of the hardy trees of recent introduction. The earliest of the Pear-trees in the collection,

Pyrus ussuriensis, opened its first flowers this year on April 30th. This tree, which is common in northern China, Korea and Manchuria and the only species which has a foot-hold in Japan where it has recently been discovered, inhabits more northern and colder regions than any other Dear-tree. If any Pear-tree proves hardy therefore in the northern interior part of this continent it should be this species; and if it proves resistant to blight it should yield the hardiest of all Pearstocks. No other species attains such a large size as is shown by the photograph made in 1919 by Wilson in Korea of a tree which was sixty feet high, with a tall trunk fourteen feet round and a head of spreading branches seventy-five feet across. The flowers are not as large as those of some of the other species, but as a flowering tree $P$. ussuriensis is one of the most beautiful of all Pear-trees for the flower-buds and the opening flowers are deeply tinged with rose-color. The fruit is subglobose, green, hard, and from one-half to three-quarters of an inch in diameter and, like that of most wild Pear-trees, is of no comestible value. Among other Pear-trees this northern species, as a young tree at least can be easily recognized by its smooth pale bark. 


\section{$2 \mathrm{BHL}$ Biodiversity Heritage Library}

1923. "Pear-trees." Bulletin of popular information - Arnold Arboretum, Harvard University 9(3), 9-9. https://doi.org/10.5962/p.321315.

View This Item Online: https://www.biodiversitylibrary.org/item/239239

DOI: https://doi.org/10.5962/p.321315

Permalink: https://www.biodiversitylibrary.org/partpdf/321315

\section{Holding Institution}

Smithsonian Libraries

\section{Sponsored by}

Biodiversity Heritage Library

\section{Copyright \& Reuse}

Copyright Status: Public domain. The BHL considers that this work is no longer under copyright protection.

Rights Holder: Arnold Arboretum of Harvard University

This document was created from content at the Biodiversity Heritage Library, the world's largest open access digital library for biodiversity literature and archives. Visit BHL at https://www.biodiversitylibrary.org. 